\title{
$\alpha 7$ Nicotinic Receptor Subunits Are Not Necessary for Hippocampal-Dependent Learning or Sensorimotor Gating: A Behavioral Characterization of Acra7-Deficient Mice
}

\author{
Richard Paylor, ${ }^{1,6}$ Michelle Nguyen, ${ }^{1}$ Jacqueline N. Crawley, ${ }^{1}$ James Patrick, ${ }^{2}$ \\ Arthur Beaudet, ${ }^{3,4}$ and Avi Orr-Urtreger ${ }^{3,5}$ \\ ${ }^{1}$ Section on Behavioral Neuropharmacology \\ Experimental Therapeutics Branch \\ National Institute of Mental Health \\ Bethesda, Maryland 20892 USA \\ ${ }^{2}$ Division of Neuroscience \\ Baylor College of Medicine \\ Houston, Texas 77030 USA \\ ${ }^{3}$ Department of Molecular and Human Genetics \\ Baylor College of Medicine \\ Houston, Texas 77030 USA \\ ${ }^{4}$ The Howard Hughes Medical Institute \\ Houston, Texas 77030 USA \\ ${ }^{5}$ Genetic Institute \\ Tel-Aviv Sourasky Medical Center \\ Tel-Aviv 64239, Israel
}

\section{Abstract}

The $\alpha 7$ nicotinic acetylcholine receptor (nAChR) subunit is abundantly expressed in the hippocampus and contributes to hippocampal cholinergic synaptic transmission suggesting that it may contribute to learning and memory. There is also evidence for an association between levels of $\alpha 7 \mathrm{nAChR}$ and in sensorimotor gating impairments. To examine the role of $\alpha 7$ nAChRs in learning and memory and sensorimotor gating, Acra 7 homozygous mutant mice and their wild-type littermates were tested in a Pavlovian conditioned fear test, for spatial learning in the Morris water

${ }^{6}$ Corresponding author. Present address: Department of Molecular and Human Genetics, Baylor College of Medicine, Houston, Texas 77030 USA. task, and in the prepulse inhibition paradigm. Exploratory activity, motor coordination, and startle habituation were also evaluated. Acra 7 mutant mice displayed the same levels of contextual and auditory-cue condition fear as wild-type mice. Similarly, there were no differences in spatial learning performance between mutant and wild-type mice. Finally, Acra 7 mutant and wild-type mice displayed similar levels of prepulse inhibition. Other behavioral responses in Acra 7 mutant mice were also normal, except for an anxiety-related behavior in the open-field test. The results of this study show that the absence of $\alpha 7$ nAChRs has little impact on normal, base-line behavioral responses. Future studies will examine the contribution of $\alpha 7 \mathrm{nAChR}$ to the enhancement of learning and sensorimotor gating following nicotine treatments.

LEARNING \& MEMORY 5:302-316 @ 1998 by Cold Spring Harbor Laboratory Press ISSN1072-0502/98 \$5.00

$$
\begin{array}{lllllllllllllll}
L & E & A & R & N & I & N & G & \underset{302}{\boldsymbol{Z}} & M & E & M & O & R & Y
\end{array}
$$




\section{Introduction}

In mammalian brain, there are two major classes of nicotinic receptors that are distinguished on the basis of ligand binding studies; one type that binds $\left[{ }^{3} \mathrm{H}\right]$ nicotine with high affinity, and the other class that binds $\left[{ }^{3} \mathrm{H}\right]$ nicotine with low affinity, but ${ }^{125}$ I-labeled $\alpha$-bungarotoxin ( $\alpha$-BTX) with high affinity. Expression studies show that neuronal nicotinic receptors are comprised of two $\alpha$ subunits and three $\beta$ subunits (Cooper et al. 1991; Bertrand and Changeux 1995). The $\alpha 7$ subunit, however, is an exception because in general, it does not assemble with other subunits in the Xenopus oocyte expression system. The $\alpha 7$ subunit appears to form a homo-oligomer receptor/channel and represents the major $\alpha$-BTX-binding protein in mammalian brain (Courturier et al. 1990; Schoepfer et al. 1990; Keyser et al. 1993; Seguela et al. 1993; Orr-Urtreger et al. 1997).

Drugs that affect acetylcholine (ACh) synaptic transmission, including those that bind at nicotinic receptors, have been shown to affect many behavioral responses such as learning and memory performance (for review, see Levin 1992) in rats and mice on tasks that require spatial memory (Decker and Majchrzak 1992; Decker et al. 1992; Curzon et al. 1996), working memory (Ohno et al. 1993; Lippiello et al. 1996), or avoidance processes (Decker et al. 1993, 1994; Meyer et al. 1994; Smith et al. 1996; Zarrindast et al. 1996). Recent findings suggest that cholinergic modulation of learning and memory performance may be mediated by the action of $\mathrm{ACh}$ and nicotine at $\alpha 7$ receptors. First, there are high levels of $\alpha 7$ containing nAChRs in the hippocampus (Dineley-Miller and Patrick 1992; Perry et al. 1993; Seguela et al. 1993; Court et al. 1995), a structure critical for the types of learning and memory affected by nicotine treatment (see Cohen and Eichenbaum 1993). Second, rapidly desensitizing currents and nicotinic-induced glutamatergic release in hippocampal cultures are mediated by presynaptic $\alpha 7$ receptors (Gray et al. 1996). Finally, there are fast, rapidly desensitizing inward currents present in CA1 interneurons that respond to $\mathrm{ACh}$ most likely through $\alpha 7 \mathrm{nAChR}$ mechanisms (Alkondon and Albuquerque 1993; Frazier et al. 1998). These studies provide evidence that $\alpha 7$ subunits are critical for various types of cholinergic synaptic transmission in the hippocampus, and support a hypothesis that $\alpha 7$ mechanisms may be important for certain types of learning and memory.

Recently, Orr-Urtreger et al. (1997) developed mice with a null mutation in the $\alpha 7$ gene (Acra 7 ). Acra7-deficient mice have normal levels of highaffinity nicotine binding, but there is an absence of $\alpha$-BTX binding. In hippocampal neurons of $\alpha 7$-deficient mice, there are no rapidly desensitizing nicotinic currents (Orr-Urtreger et al. 1997) supporting the possibility that the $\alpha 7$ subunits are important for some aspects of hippocampal function. With these mice it is now possible to examine the functional impact of $\alpha 7$ deficiencies on normal, base-line learning and memory. In addition, it will be possible to study the role of $\alpha 7$ receptors in nicotine-induced changes in learning performance.

Rapidly incoming sensory stimuli are filtered in the central nervous system by use of normal, inhibitory gating mechanisms. There is strong evidence for an association between $\alpha 7 \mathrm{nAChRs}$ and sensory gating as assessed by recording auditoryevoked potentials or by use of the prepulse inhibition paradigm. First, nicotine increases sensory gating in humans and animals (Adler et al. 1992; Acri et al. 1994a,b; Curzon et al. 1994; Freedman et al. 1994; Bickford and Wear 1995; Stevens et al. 1995; Kumari et al. 1997; Stevens and Wear 1997). Second, intraventricular injections of $\alpha$-BTX disrupt hippocampal auditory gating (Luntz-Leybman et al. 1992). Third, there is a significant correlation between levels of sensory gating of auditory-evoked potentials and $\alpha$-BTX binding in the hippocampus among inbred strains of mice (Stevens et al. 1996). This study also reported that the pattern of $\alpha$-BTX binding in the hippocampus was consistent with $\alpha 7$ mRNA in situ hybridization across four inbred strains of mice. Fourth, using the prepulse inhibition paradigm, Bullock et al. (1997) showed that there was a significant correlation between levels of prepulse inhibition and auditory-evoked potentials in the hippocampus. In addition, Bullock et al. (1997) reported a correlation between levels of prepulse inhibition and $\alpha$-BTX that was consistent with the correlation reported by Stevens et al. (1996) using the auditory-evoked potential preparation. Finally, Freedman et al. (1997) showed that gating differences associated with schizophrenia (e.g., Freedman et al. 1983; Geyer and Braff 1987; Braff and Geyer 1990) show linkage to human chromosome 15 in a region near the $\alpha 7$ locus. Thus, there is increasing evidence for a relationship between the $\alpha$-BTX binding most likely at the $\alpha 7 \mathrm{nAChR}$ and differences in sensory gating. With the Acra7-deficient mice, it is possible to test the hypothesis that different levels of $\alpha 7 \mathrm{nAChRs}$ are associated with differential sensorimotor gating.

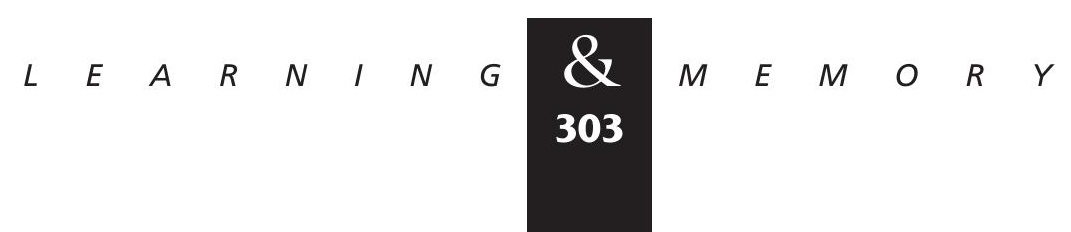


Paylor et al.

As a first step to understanding the role of $\alpha 7$ nAChRs in behavior, we evaluated base-line learning and memory performance and sensorimotor gating in Acra7-deficient and wild-type mice. It was also important to evaluate several general behavioral responses of the Acra 7 mutant mice by use of a test battery (Crawley and Paylor 1997) because nicotine also influences the startle response, locomotor activity, and anxiety-related behaviors (Marks et al. 1986, 1989; Acri et al. 1991; Cao et al. 1993; Decker et al. 1994). The results show that $\alpha 7$-deficient mice are similar to wildtype mice in a wide variety of behavior tests suggesting that normal $\alpha 7$ receptor function is not essential for the base-line expression of various normal behavioral responses.

\section{Materials and Methods}

\section{ANIMALS}

Acra7-deficient mice were generated as described previously (Orr-Urtreger et al. 1997). Behavioral testing was performed on Acra 7 homozygous deficient and wild-type mice that were originally derived in $129 / \mathrm{SvEv}$ ES cells but were backcrossed to $\mathrm{C} 57 \mathrm{BL} / 6 \mathrm{~J}$ mice for six generations after germ-line transmission; heterozygotes were not studied. Mice were shipped from Baylor College of Medicine and held at National Institutes of Health (NIH) in quarantine for $\sim 8$ weeks. The mice were 3-4 months old at the beginning of testing. Mice were housed three to five per cage in a room with a $12 \mathrm{hr}$ light/dark cycle (lights on at $0600 \mathrm{hr}$ ) with access to food and water ad lib. In general, behavioral testing was performed between 0700 and $1300 \mathrm{hr}$. An experimenter that was blind to the genotypes of the mice conducted all experiments. Fifteen Acra 7 -deficient ( 8 females and 7 males) and 11 wild-type ( 8 females and 4 males) were tested. All behavioral testing procedures were approved by the National Institute of Mental Health (NIMH) Animal Care and Use Committee and followed the NIH Guidelines, "Using Animals in Intramural Research."

\section{NEUROLOGICAL SCREEN}

A simple neurological screen for motor and sensory responses was used first. In this screen, a mouse was weighed and its body temperature was assessed with a rectal probe (Thermalert TH-5). Other physical features were recorded including the presence of whiskers, bald hair patches, palpe- bral closure, exophthalmos, and piloerection. The mouse was then placed into an empty cage and observed for $1 \mathrm{~min}$. The presence of several behavioral responses was recorded (i.e., wild running, freezing, licking, jumping, sniffing, rearing, movement throughout the cage, and defecation). Postural reflexes were then evaluated by first determining if the mouse would splay its limbs when in a cage that is quickly lowered and moved from side to side. The righting reflex, whisker touch response, eye blink, and ear twitch were then evaluated. Several simple motor responses were evaluated by use of a wire suspension test and a vertical pole test. In the wire suspension test, the mouse was suspended from a single wire $(2 \mathrm{~mm})$ by its forepaws. The time that the mouse hung on the wire was recorded. In the vertical pole test, a mouse was placed facing up on a cloth-tape-covered pole (1.9-cm diam., $43-\mathrm{cm}$ long). The end of the pole was lifted to a vertical position and the time a mouse stayed on the pole was recorded. These values are converted to a pole test score: Fell before the pole reached $45^{\circ}$ or $90^{\circ}$ angle $=0$ or 1 , respectively; fell in $0-10 \mathrm{sec}=2,11-20 \mathrm{sec}=3$, $21-30 \mathrm{sec}=4,31-40 \mathrm{sec}=5,41-50 \mathrm{sec}=6,51-$ $60 \mathrm{sec}=7$; stayed on $60 \mathrm{sec}$ and climbed halfway down the pole $=8$, climbed to the lower half of the pole $=9$; climbed down and off in: $51-60 \mathrm{sec}=10$, $41-50 \mathrm{sec}=11,31-40 \mathrm{sec}=12,21-30 \mathrm{sec}=13$, $11-20 \mathrm{sec}=14,1-20 \mathrm{sec}=15$. Finally, the animal was placed in the center of a platform $(20 \mathrm{~cm})$, and the latency to move to the edge, and the number of times the mouse reaches its head over the edge, were recorded.

Two-way (genotype $\times$ gender) analyses of variance (ANOVA) were used to analyze the wire suspension and platform test data. Nonparametric statistical tests were used to analyze the remaining data.

\section{LOCOMOTOR ACTIVITY IN AN OPEN FIELD}

One to two days after the neurological screen, locomotor activity was evaluated by placing mice into an open-field arena. Each subject was placed in the center of a clear plexiglas $(40 \times 40 \times 30 \mathrm{~cm})$ chamber in standard room-lighting conditions. Activity in the open field was quantitated by a computer-operated Digiscan optical animal activity system [RXYZCM (8), Omnitech Electronics] containing eight photoreceptor beams on each side of the arena, which divides the arena into 64 equally sized squares. Horizontal activity (locomotor activity measured by number of photobeam interrup-

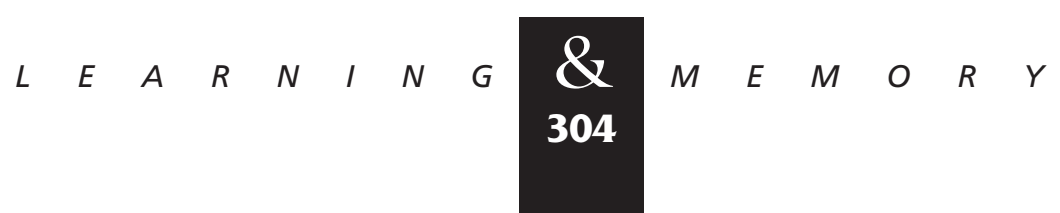


tions), vertical activity (rearing measured by number of photobeam interruptions), total distance (cm), and center distance (i.e., the 16 equally sized squares in the center of the arena) were recorded. The center distance was also divided by the total distance to obtain a center distance/total distance ratio. The center distance/total distance ratio can be used as an index of anxiety. Data were collected in 2 min intervals over a 30-min test session.

Locomotor activity data were analyzed by use of a three-way (genotype $\times$ gender $\times$ blocks of 2 min) ANOVA with repeated measures. Significant interactions were subsequently analyzed by simple effects tests.

\section{LIGHT $\leftrightarrow$ DARK EXPLORATION}

Two days later, mice were tested in the Light $\leftrightarrow$ Dark exploration test. The Light $\leftrightarrow$ Dark exploration test consists of a polypropylene cage $(44 \times 21 \times 21 \mathrm{~cm})$ unequally divided into two chambers by a black partition containing a small opening. The large chamber is open and brightly illuminated, whereas the small chamber is closed and dark. Mice were placed into the lit side and allowed to move freely between the two chambers for $10 \mathrm{~min}$. Photocells located in the opening detected transitions of the mouse between the two chambers. The total number of transitions and time in the dark side were recorded.

Data were analyzed by two-way (genotype $\times$ gender) ANOVA.

\section{ROTAROD TEST}

Motor coordination and balance were tested in the afternoon with an accelerating rotarod (UGO Basile Accelerating Rotarod). The rotarod test was performed by placing a mouse on a rotating drum and measuring the time each animal was able to maintain its balance on the rod. The speed of the rotarod accelerated from 4 to $40 \mathrm{rpm}$ over a 5-min period. Mice were given four trials with a 30 - to 60-min intertrial rest interval.

Rotarod data were analyzed with a three-way (genotype $\times$ gender $\times$ trial) ANOVA with repeated measures. Significant interactions were subsequently analyzed by use of simple effects tests.

\section{STARTLE AND PREPULSE INHIBITION}

Three days after rotarod testing, prepulse inhibition of acoustic startle responses was measured by the SR-Lab System (San Diego Instruments, San Diego, CA) as described previously (Paylor and Crawley 1997). A test session began by placing a mouse in the plexiglas cylinder where it was left undisturbed for $5 \mathrm{~min}$. A test session consisted of seven trial types. One trial type was a $40-\mathrm{msec}$, 120-dB sound burst used as the startle stimulus. There were five different acoustic prepulse plus acoustic startle stimulus trials. The prepulse sound was presented $100 \mathrm{msec}$ before the startle stimulus. The 20-msec prepulse sounds were 74, 78, 82, 86 , or $90 \mathrm{~dB}$. Finally, there were trials in which no stimulus was presented to measure base-line movement in the cylinders. Six blocks of the seven trial types were presented in pseudorandom order such that each trial type was presented once within a block of seven trials. The average intertrial interval was $15 \mathrm{sec}$ (ranged from 10 to $20 \mathrm{sec}$ ). The startle response was recorded for $65 \mathrm{msec}$ (measuring the response every $1 \mathrm{msec}$ ) starting with the onset of the startle stimulus. The background noise level in each chamber was $70 \mathrm{~dB}$. The maximum startle amplitude recorded during the 65-msec sampling window was used as the dependent variable.

The next day, prepulse inhibition of a tactile startle response was measured. A piece of copper tubing was inserted into the chamber so that an air-puff stimulus could be applied directly to the body of the mouse. Each mouse was tested by the same procedures and trial types described for prepulse inhibition of the acoustic startle response, but the startle stimulus was a 40-msec, 12-psi burst of air.

The following formula was used to calculate percent prepulse inhibition of a startle response: 100[(startle response on acoustic prepulse plus startle stimulus trials/startle response alone trials) $\times 100$ ] Thus, a high percent prepulse inhibition value indicates good prepulse inhibition, that is, the subject showed a reduced startle response when a prepulse stimulus was presented compared with when the startle stimulus was presented alone. Conversely, a low percent prepulse inhibition value indicates poor prepulse inhibition, that is, the startle response was similar with and without the prepulse.

Acoustic and tactile response amplitude data were analyzed by use of two-way (gender $\times$ genotype) ANOVAs.

Prepulse inhibition data were analyzed with a three-way (genotype $\times$ gender $\times$ prepulse sound level) ANOVA with repeated measures. Subsequently, significant interactions were analyzed by simple effects tests.

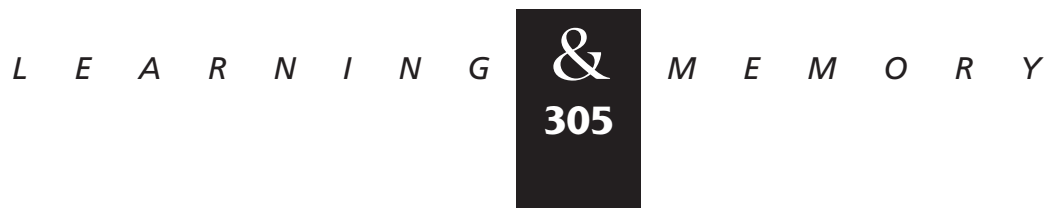


HABITUATION OF THE ACOUSTIC STARTLE RESPONSE

Three days later, habituation of the acoustic startle response was measured. One hundred startle stimuli (120 dB, $40 \mathrm{msec}$ ) were presented to each mouse. The average interstimulus interval was $15 \mathrm{sec}$. The maximum response to each stimulus was recorded.

Startle habituation data were analyzed by use of a three-way (genotype $\times$ gender $\times$ stimulus number) ANOVA with repeated measures. Significant interactions were subsequently analyzed by simple effects tests.

\section{PAVLOVIAN CONDITIONED FEAR}

Three weeks later, performance in a conditioned fear task was measured as described by Paylor et al. (1994). One wall of the test chamber was metal, another was white plastic, and the remaining two were clear plexiglas. The bottom of the test chamber was a grid floor that was used to deliver an electric shock. The test chamber was placed inside a sound-attenuated chamber. Mice were observed through windows in the front of the sound-attenuated chamber. A mouse was placed in the test chamber (house lights ON) and allowed to explore freely for $2 \mathrm{~min}$. A white noise (80 dB), which served as the conditioned stimulus (CS), was presented for $30 \mathrm{sec}$ followed by a mild (2 sec, $0.5 \mathrm{~mA}$ ) foot shock, which served as the unconditioned stimulus (US). Two minutes later, another CS-US pairing was presented. The mouse was removed from the chamber $30 \mathrm{sec}$ later and returned to its home cage. Freezing behavior was recorded by use of the standard interval-sampling procedure every $10 \mathrm{sec}$. Responses (run, jump, and vocalize) to the foot shock were recorded. If a mouse did not show any response to the foot shock it was excluded from the analysis.

Twenty-four hours later, the mouse was placed back into the test chamber for $5 \mathrm{~min}$ and the presence of freezing behavior was recorded every 10 sec (context test). Two hours later, the mouse was tested for its freezing to the auditory CS. For the auditory CS test, an empty mouse cage replaced the test chamber. In addition, a container with 1.0 $\mathrm{ml}$ of vanilla extract was placed in the sound-attenuated chamber. Finally, the sound-attenuated chamber was illuminated with red house lights. There were two phases during the auditory CS test. In the first phase (pre-CS), freezing was recorded for 3 min without the auditory CS. In the second phase, the auditory CS was turned on and freezing was recorded for another $3 \mathrm{~min}$. The number of freezing intervals was converted to a percent freezing value. For the auditory CS test, the percent freezing value obtained during the pre-CS period was subtracted from the percent freezing value when the auditory CS was present.

Context and CS test data were analyzed by a two-way (genotype $\times$ gender) ANOVA with repeated measures.

\section{SPATIAL LEARNING IN THE MORRIS WATER TASK}

Two weeks later, mice were trained in the Morris water task (Morris 1981) to locate a hidden escape platform in a circular pool (1.38 meters diam.) of water (Upchurch and Wehner 1988). Each mouse was given 12 trials a day, in blocks of 4 trials for 3 consecutive days. The time taken to locate the escape platform (escape latency) and the distance traveled were determined. After trials 24 and 36, each animal was given a probe trial. During the probe trial, the platform was removed and each animal was allowed 60 sec to search the pool. The amount of time that each animal spent in each quadrant was recorded (quadrant search time). The number of times a subject crossed the exact location of the platform during training was determined, and compared with crossings of the equivalent location in each of the other quadrants (platform crossing). The data for the two probe trials were averaged.

Escape latency and distance traveled (data not shown) data were analyzed with three-way (gender $\times$ genotype $\times$ trial block) ANOVAs with repeated measures. Post-hoc comparisons were made by use of simple effects and Newman-Keuls tests. Selective search data in the probe trial were analyzed by individual one-way (quadrants) repeated ANOVAs and Newman-Keuls post-hoc comparison tests. Two-way ANOVA (genotype $\times$ gender) were used to compare the quadrant search time and platform crossing data for the training quadrant only between mutant and wild-type mice.

\section{HOT-PLATE TEST}

Two weeks later, the hot-plate test was used to evaluate the sensitivity to a painful stimulus. Mice were placed on a $55.0^{\circ} \mathrm{C}( \pm 0.3)$ hot plate, and the latency to the first hind-paw response was re-

$$
\begin{array}{llllllllllllllll}
L & E & A & R & N & I & N & G & \underset{306}{\mathbf{Z}} & M & E & M & O & R & Y
\end{array}
$$


corded. The hind-paw response was either a foot shake or a paw lick.

Hot-plate data were analyzed by use of a twoway (gender $\times$ genotype) ANOVA.

\section{Results}

\section{NEUROLOGIC SCREEN}

As can be seen in Table 1, Acra7-deficient mice were healthy as assessed by body weight and body temperature, and they showed no abnormal physical features. Mutant mice also displayed normal neurological responses and reflexes. Table 1 also shows that there was no difference between mutant and wild-type mice in the latency to the first hind-paw response in the hot-plate test.

\section{LOCOMOTOR ACTIVITY}

Acra7-deficient mice tended to be less active and rear less often than wild-type mice. However, the horizontal activity (Fig. 1A) and vertical activity (Fig. 1B) were not statistically different between the

Table 1: General motor and sensory responses of Acra7-deficient and wild-type mice

\begin{tabular}{|c|c|c|}
\hline & Wild type & Acra7-deficient \\
\hline \multicolumn{3}{|l|}{ Physical characteristics } \\
\hline weight & $26.5( \pm 1.2)$ & $28.1( \pm 1.3)$ \\
\hline body temperature & $37.4( \pm .1)$ & $37.3( \pm 0.1)$ \\
\hline whiskers (\% with) & 50 & 80 \\
\hline bald patches (\% with) & 18 & 13 \\
\hline palpebral closure (\% with) & 0 & 0 \\
\hline exophthalmos (\% with) & 0 & 0 \\
\hline piloerection (\% with) & 0 & 0 \\
\hline \multicolumn{3}{|l|}{ General behavioral observations } \\
\hline \multicolumn{3}{|l|}{ (\% subjects displaying response) } \\
\hline wild running & 0 & 0 \\
\hline freezing & 0 & 0 \\
\hline sniffing & 100 & 100 \\
\hline licking & 0 & 0 \\
\hline rearing & 100 & 100 \\
\hline jumping & 0 & 0 \\
\hline defecation & 6 & 9 \\
\hline urination & 6 & 0 \\
\hline move around entire cage & 100 & 100 \\
\hline \multirow{2}{*}{\multicolumn{3}{|c|}{$\begin{array}{l}\text { Sensorimotor reflexes } \\
(\% \text { subjects displaying "normal response") }\end{array}$}} \\
\hline & & \\
\hline cage movement & 100 & 100 \\
\hline righting & 100 & 100 \\
\hline whisker response & 100 & 100 \\
\hline eye blink & 100 & 100 \\
\hline ear twitch & 100 & 100 \\
\hline \multicolumn{3}{|l|}{ hot-plate test } \\
\hline [latency (sec) to first hind-paw response] & $6.42( \pm .69)$ & $5.95( \pm .61)$ \\
\hline \multicolumn{3}{|l|}{ Motor responses } \\
\hline wire suspension time $(\mathrm{sec})$ & $40( \pm 6)$ & $48( \pm 5)$ \\
\hline pole test score & $6( \pm 2)$ & $6( \pm 1)$ \\
\hline tail suspension (\% with normal response) & 100 & 100 \\
\hline \multicolumn{3}{|l|}{ Elevated platform } \\
\hline latency to edge (sec) & $1( \pm 0)$ & $1( \pm .3)$ \\
\hline no. of exploratory nose pokes & $9( \pm 1)$ & $8( \pm 1)$ \\
\hline
\end{tabular}

Data represent the mean ( \pm S.E.M.).

$$
\begin{array}{lllllllllllllll}
\hline & E & A & R & N & I & N & G & \underset{307}{\mathbf{Z}} & M & E & M & O & R & Y
\end{array}
$$


Paylor et al.

A

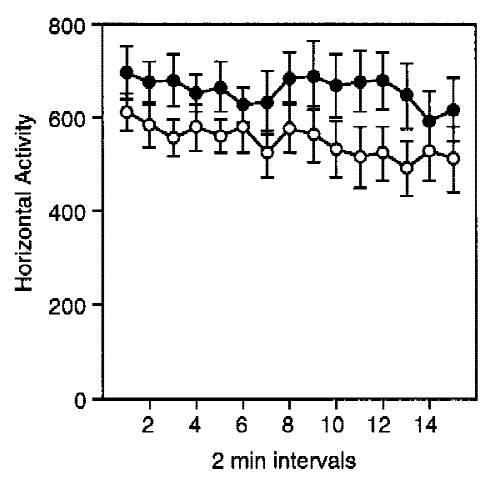

B



$\mathrm{C}$

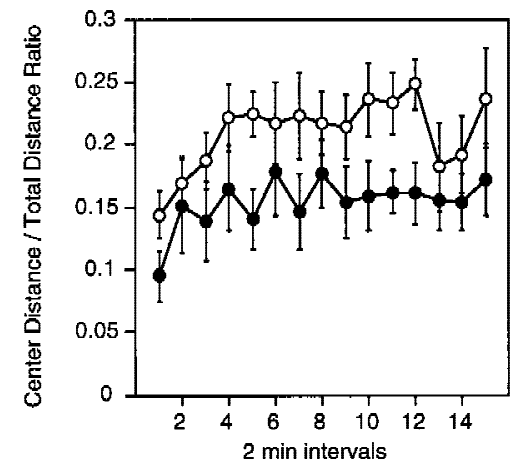

Figure 1: Open-field activity test. Averages ( \pm S.E.M.) for horizontal activity $(A)$, vertical activity $(B)$, and center distance/ total distance ratio $(C)$ for Acra7-deficient and wild-type mice across the 30-min test are shown. $(\bullet)$ Wild type; $(O)$ $\alpha 7$-deficient.

two genotypes [horizontal activity, $F(1,22)=2.681$, $P=0.1157$; vertical activity, $F(1,22)=2.155$, $P=0.1562]$. Regardless of genotype, female mice had significantly higher horizontal activity counts than male mice $[F(1,22)=5.628, P=0.0268]$. The female mice did not show more vertical activity than male mice $[F(1,22)=2.64, P=0.612]$, and the genotype $\times$ gender interactions for horizontal activity and vertical activity were not significant [horizontal activity, $F(1,22)=0.879, P=0.358$; vertical activity, $F(1,22)=1.393, P=0.25$ ]. Finally, there were no significant changes in horizontal activity or vertical activity across time, and the interactions with time were not significant $(P>0.19)$.

Figure 1C shows that the Acra 7 -deficient mice did spend a significantly greater proportion of time in the center of the open field compared with the wild-type mice as expressed by the center distance/total distance ratio $[F(1,22)=10.171$, $P=0.0042]$, indicating that mutant mice may have different anxiety-related behavioral responses. Regardless of genotype, female mice also spent a significantly greater proportion of time in the

center of the open field compared with the male mice $[F(1,22)=9.533, P=0.0054]$. The genotype $\times$ gender interaction, however, was not significant $[F(1,22)=0.966, P=0.336]$. The change of the ratio values across time was not significant, and the interactions with time were not significant $(P>0.06)$.

\section{LIGHT $\leftrightarrow$ DARK EXPLORATION TEST}

The behavioral responses of Acra7-deficient and wild-type mice in the Light $\leftrightarrow$ Dark test for anxiety-related behaviors were similar (Fig. 2A,B).
There were no significant differences between Acra7-deficient mice and wild-type mice in the number of transitions between the light and dark



B



Figure 2: Exploratory activity in the Light $\leftrightarrow$ Dark test for anxiety-related behaviors. Averages ( \pm S.E.M.) for number of transitions between the light and dark sides $(A)$ and time spent in the dark (B) for Acra7 mutant and wild-type mice are shown.

$$
\begin{array}{lllllllllllllll}
\hline & E & A & R & N & I & N & G & \underset{308}{\boldsymbol{Q}} & M & E & M & O & R & Y
\end{array}
$$


compartments $[F(1,22)=0.419, P=0.524]$, nor in the total time spent in the dark compartment $[F(1,22)=1.051, P=0.316]$. Regardless of genotype, female mice had significantly higher light $\leftrightarrow$ dark transitions $[F(1,22)=17.935, P=0.0003]$, and spent less time in the dark $[F(1,22)=16.821$, $P=0.0005]$ compared with the male mice. However, the genotype $\times$ gender interactions were not significant for the number of transitions $[F(1,22)=1.369, P=0.254]$ or total time in the dark $[F(1,22)=0.486, P=0.492]$.

\section{ROTAROD TEST}

The performance on the rotarod test was similar between Acra7-deficient and wild-type mice (Fig. 3). Overall, the amount of time mice spent on the rotarod increased with training $[F(3,66)=20.416, P=0.00001]$. Acra 7 -deficient and wild-type mice spent equal amounts of time on the rotarod $[F(1,22)=0.0001, P=0.999]$. Regardless of genotype, female mice spent significantly more time on the rotarod than male mice $[F(1,22)=21.378, P=0.0001]$. However, the genotype $\times$ gender interaction was not significant $[F(1,22)=0.307, P=0.585]$. In addition, there were no significant interactions with the number of training trials $(P>0.06)$.

ACOUSTIC STARTLE AND PREPULSE INHIBITION OF THE ACOUSTIC STARTLE RESPONSE

Figure $4 \mathrm{~A}$ presents the acoustic startle response to the $120-\mathrm{dB}$ sound stimulus. The startle

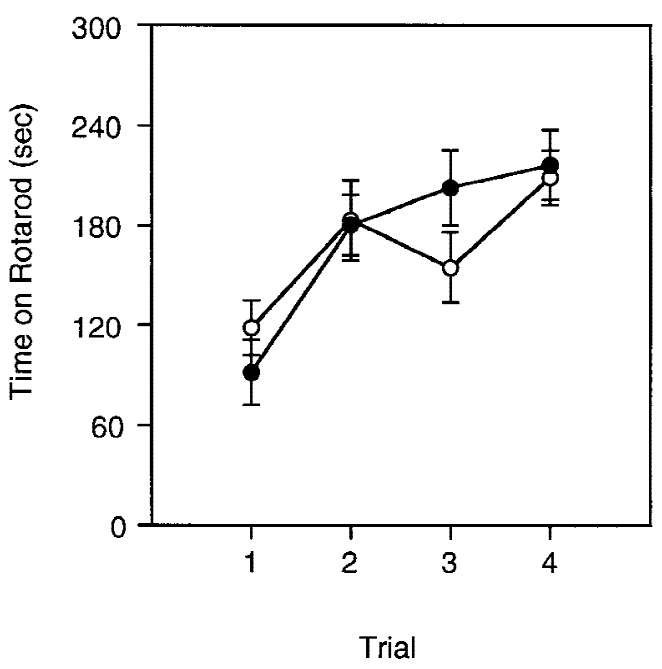

Figure 3: Rotarod test. The averages ( \pm S.E.M.) for time spent on the rotarod across four test trials for Acra7deficient $(\bigcirc)$ and wild-type $(0)$ mice are shown.
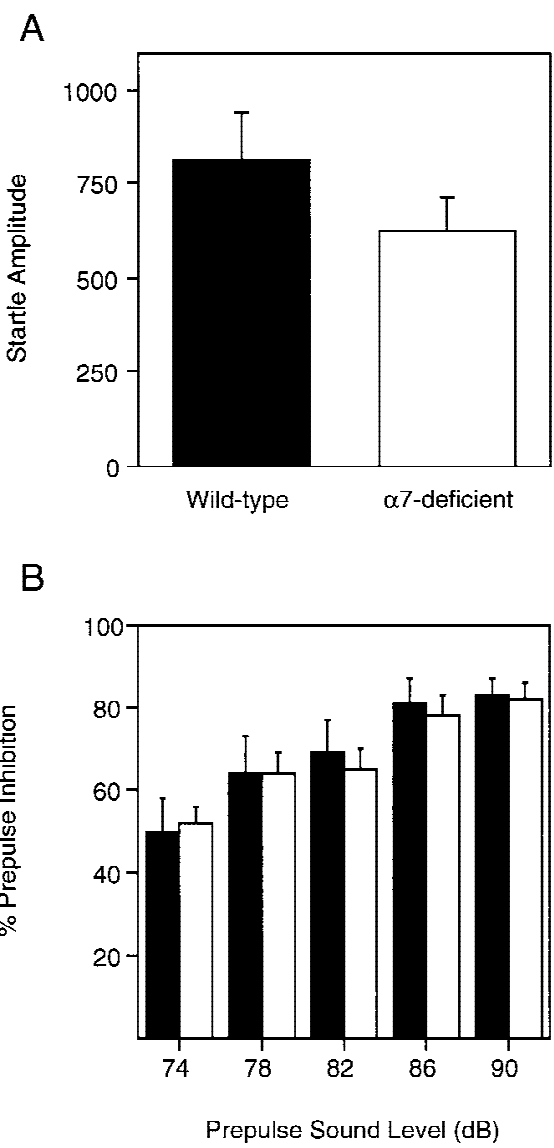

Figure 4: Acoustic startle response and prepulse inhibition of the acoustic startle response. Averages ( \pm S.E.M.) for startle amplitude to the 120-dB stimulus $(A)$ and levels $(\%)$ of prepulse inhibition of the acoustic startle response $(B)$ for Acra7-deficient and wild-type mice are shown. (Solid bars) Wild type; (open bars) $\alpha 7$-deficient.

amplitude was similar between Acra7-deficient and wild-type mice $[F(1,22)=1.73, P=0.202]$. There was also no significant difference in the startle response between male and female mice $[F(1,22)=0.019, \quad P=0.892], \quad$ and the genotype $\times$ gender interaction was not significant $[F(1,22)=0.293, P=0.593]$.

Acra7-deficient mice and wild-type mice displayed similar levels of prepulse inhibition of the acoustic startle response (Fig. 4B). In general, levels of prepulse inhibition increased across the prepulse sound levels $[F(4,88)=44.821, P=0.0001]$. There were no differences in the levels of prepulse inhibition of the acoustic startle response between Acra 7 -deficient and wild-type mice $[F(1,22)=0.355$, $P=0.5575]$. Regardless of genotype, higher levels of prepulse inhibition were recorded for male mice than female mice $[F(1,22)=7.994, P=0.0098]$. The

$$
\begin{array}{llllllllllllllll}
\hline & E & A & R & N & I & N & G & \mathbf{Z} & M & E & M & O & R & Y
\end{array}
$$


genotype $\times$ gender interaction was not significant, however $[F(1,22)=0.439, \quad P=0.5146]$. There was a significant gender $\times$ prepulse interaction $[F(4,88)=4.028, P=0.0048]$. Simple effects analysis of the gender $\times$ prepulse level interaction showed that male mice had higher levels of prepulse inhibition of the acoustic startle response with 78-, 82-, 86-, and 90-dB $(P<0.037)$ prepulse sounds, but not with $74 \mathrm{~dB}(P=0.106)$. The other interactions were not statistically significant $(P>0.18)$.

\section{TACTILE STARTLE AND PREPULSE INHIBITION OF THE TACTILE STARTLE RESPONSE}

The startle amplitude to the tactile (air puff) stimulus was not significantly different between Acra7-deficient and wild-type mice (Fig. 5A) $[F(1,22)=0.796, P=0.3821]$. There was also no significant difference in the startle response between male and female mice $[F(1,22)=1.136$, $P=0.298]$, and the genotype $\times$ gender interaction was not significant $[F(1,22)=0.812, P=0.377]$.

Consistent with the observations made using an acoustic startle stimulus, there was no significant difference in the levels of prepulse inhibition of the tactile startle response between Acra7-deficient and wild-type mice (Fig. 5B) $[F(1,22) \mathrm{T}=0.344, P=0.5637]$. In general, levels of prepulse inhibition increased with increases in the intensity of the prepulse $[F(4,88)=111.021$, $P=0.00001]$. There was a significant genotype $\times$ prepulse sound level interaction $[F(4,88)=4.275$, $P=0.0033]$. Simple effects analysis of this interaction showed that mutant mice had higher levels of prepulse inhibition of the tactile startle response than wild-type mice with the $78-\mathrm{dB}(P=0.01)$ prepulse sounds, but not with $74,82,86$, or $90 \mathrm{~dB}$ $(P>0.24)$. Regardless of genotype, overall, male mice had significantly higher levels of prepulse inhibition compared with female mice $[F(1,22)=4.509$, $P=0.0452]$.

\section{HABITUATION OF THE ACOUSTIC STARTLE RESPONSE}

Figure 6 presents the acoustic startle response habituation profile for Acra7-deficient and wildtype mice. The data are averaged across blocks of 10 trials. In general, the startle amplitude decreased with repeated presentation of the startle

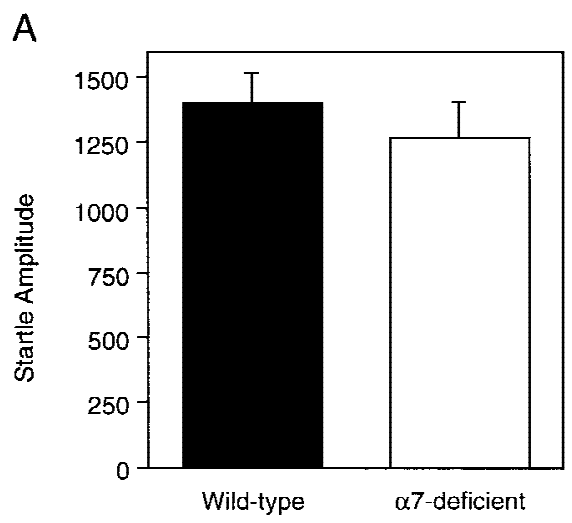

B

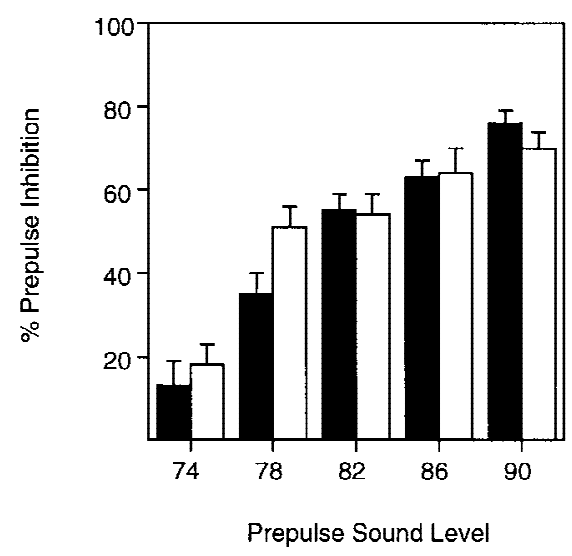

Figure 5: Tactile startle response and prepulse inhibition of the tactile startle response. Averages ( \pm S.E.M.) for tactile startle amplitude to the 12 psi air-puff stimulus $(A)$ and levels (\%) of prepulse inhibition of the tactile startle response $(B)$ for Acra7-deficient and wild-type mice are shown. (Solid bars) Wild type; (open bars) $\alpha 7$-deficient.

stimulus $[F(9,198)=4.863, \quad P=0.00001]$. There was, however, no significant difference between Acra 7 -deficient and wild-type mice $[F(1,22)=0.906$, $P=0.3515]$. There was no significant difference between male and female mice $[F(1,22)=0.699$, $P=0.412]$ and the genotype $\times$ gender interaction was not significant $[F(1,22)=0.078, P=.782]$. No other interactions were significant $(P>0.75)$.

\section{PAVLOVIAN CONDITIONED FEAR}

Acra7-deficient and wild-type mice displayed similar levels of conditioned fear (Fig. 7A,B). There was no difference between mutant and wild-type mice in the levels of freezing during both the context test $[F(1,20)=0.289, P=0.5968]$ and

$$
\begin{array}{lllllllllllllll}
\hline & E & A & R & N & I & N & G & \underset{310}{\boldsymbol{Z}} & M & E & M & O & R & Y
\end{array}
$$




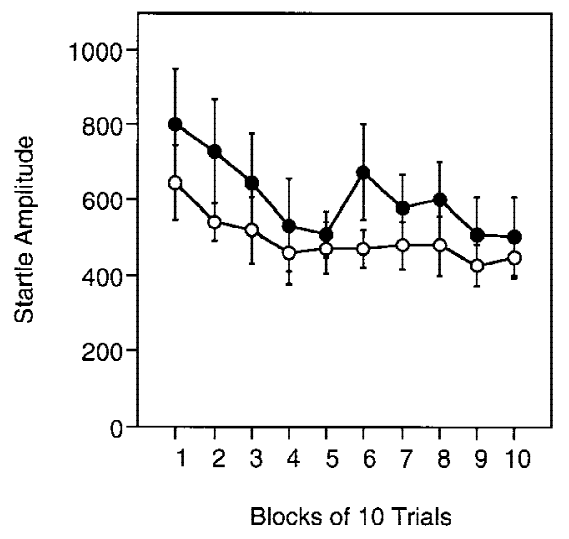

Figure 6: Habituation of the acoustic startle response. The averages ( \pm S.E.M.) for startle response to repeated presentations of a 120-dB startle stimulus for Acra7-deficient $(\bigcirc)$ and wild-type $(\bullet)$ mice are shown.

the auditory CS test $[F(1,20)=0.930, P=0.3463]$. There were no differences between male and female mice on the context or auditory CS test $[F(1,20)=0.989, P=0.332$, and $F(1,20)=2.319$, $P=0.143$, respectively]. Similarly, the genotype $\times$ gender interactions were not significant $(P>0.247)$. One mutant and one wild-type mouse were excluded from the analysis because they did not show a run, jump, or vocalization response to the foot shock.

\section{SPATIAL LEARNING IN THE MORRIS WATER TASK}

Spatial learning performance of Acra7-deficient and wild-type mice was similar. Figure $8 \mathrm{~A}$ presents the time it took for wild-type and mutant mice to find the hidden platform expressed as escape latency. The time taken to find the escape platform decreased with training $[F(8,168)=11.281, P=0.00001]$. Overall, Acra 7 deficient mice took significantly less time to find the escape platform than the wild-type mice [main effect of genotype $=F(1,21)=6.811$, $P=0.0164]$. Regardless of genotype, female mice took significantly less time to find the platform compared with male mice [main effect of gen$\operatorname{der}=F(1,21)=20.522, \quad P=0.0002]$. The genotype $\times$ gender interaction was not significant $[F(1,21)=3.154, P=0.090]$. The interactions with trials also were not significant $(P>0.08)$. One wild-type male mouse had to be excluded because it floated during many of the training trials and during the probe trials.

Figure $8, \mathrm{~B}$ and $\mathrm{C}$, presents the average probe data (quadrant search time and platform crossings) from the probes after day 2 and day 3. Wildtype mice and Acra7-deficient mice selectively searched the correct location in the pool in which the platform had been located during training. Both wild-type and Acra7-deficient mice spent significantly more time in the training quadrant compared with the other quadrants [wildtype, $F(3,27)=8.352, P=0.0004 ;$ Acra 7 -deficient, $F(3,42)=6.594, P=0.0009$. Newman-Keuls posthoc comparisons $=$ trained more than all other quadrants, $P<0.05]$. In addition, wild-type and Acra 7-deficient mice crossed the training site more often than equivalent sites in the other three quadrants [wild-type, $F(3,27)=7.925, \quad P=0.0006$; Acra7-deficient, $F(3,42)=8.53, P=0.0002$. Newman-Keuls post-hoc comparisons $=$ trained more than all other quadrants, $P<0.01]$. The actual time

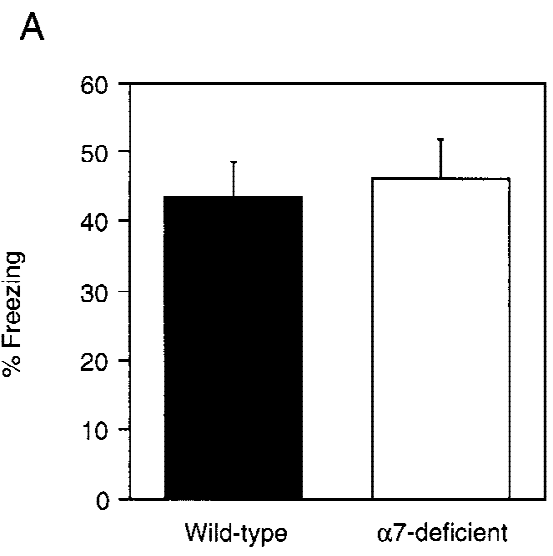

B



Figure 7: Pavlovian conditioned fear for Acra7-deficient and wild-type mice. $(A)$ The percent intervals freezing during the context test $(A)$ and CS test $(B)$. Percent freezing for the CS test was obtained as described in the text. Data are expressed as the average percent freezing ( \pm S.E.M.).

$$
\begin{array}{lllllllllllllll}
\hline & E & A & R & N & I & N & G & \begin{array}{l}
\boldsymbol{Q} \\
\mathbf{3 1 1}
\end{array} & M & E & M & O & R & Y
\end{array}
$$


A

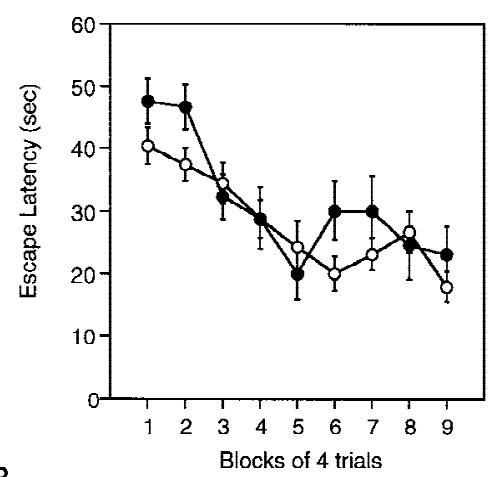

B

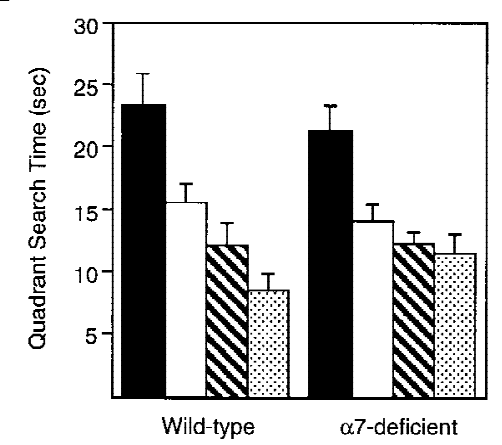

C

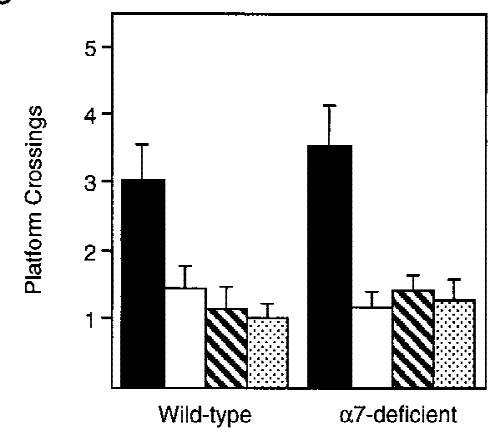

Figure 8: Spatial-learning performance in the Morris water task for Acra7-deficient and wild-type mice. (A) Average ( \pm S.E.M.) time to find the platform (escape latency) during training. $(\bullet)$ Wild type; $(O) \alpha 7$-deficient. $(B, C)$ Average ( \pm S.E.M.) probe data (quadrant search time and platform crossings) from the probes after day 2 and day 3. (Solid bars) Trained; (open bars) left; (hatched bars) right; (stippled bars) opposite.

spent in the training quadrant was not statistically different between Acra7-deficient and wild-type mice $[F(1,21)=0.278, P=0.6038]$. Similarly, the number of times Acra7-deficient and wild-type mice crossed the exact site where the platform had been located was not different $[F(1,21)=0.816$, $P=0.3765]$. In general, female mice crossed the training site more often than the male mice $[F(1,21)=6.047, P=0.0227]$, but did not spend any more time than male mice in the correct quadrant of the pool $[F(1,21)=3.462, P=0.076]$. The genotype $\times$ gender interactions were also not significant $(P>0.43)$.

\section{Discussion}

The behavioral responses of Acra7-deficient mice were remarkably similar to wild-type mice. Mutant mice displayed similar levels of Pavlovian conditioned fear to both contextual and auditorycue stimuli associated with a foot shock. Mutant and wild-type mice also displayed similar spatial learning performance in the Morris water task. There was also no evidence for an impaired prepulse inhibition response in mutant mice. Other general behaviors such as locomotor activity, rearing, rotarod performance, acoustic startle response, tactile startle response, habituation of an acoustic startle stimulus, and hind-paw foot responses to noxious stimulation were similar between mutant and wild-type mice. There were significant gender differences on several tests, but there were no data indicating that these gender differences were genotype specific. These results clearly indicate that deficiency of the $\alpha 7 \mathrm{nACh}$ receptor has little functional impact on many normal mouse behaviors.

Acra7-deficient mice did spend a significantly greater proportion of their total distance traveled in the open field in the center of the arena as compared with wild-type mice. This finding suggests that Acra7-deficient mice may have less anxietyrelated behavioral responses compared with wild types. However, this apparent difference was not supported by the Light $\leftrightarrow$ Dark exploration test, another assay of anxiety-related behaviors. Therefore, further studies are necessary to understand the nature of the difference in the open field including testing mutant and wild-type mice on a series of other tests that assay for anxiety-related behaviors such as the elevated plus maze or the elevated circle maze.

In addition, Acra7-deficient mice also located the hidden platform in the Morris water task significantly faster than wild-type mice. However, this was a subtle difference and was not supported by the distance traveled data (not shown). More importantly, there was no difference between Acra 7and wild-type mice in the search behavior during the probe trials. Several investigators have shown that performance during training often does not correlate with performance during the probe trial

$$
\begin{array}{lllllllllllllll}
L & E & A & R & N & I & N & G & \underset{312}{\mathbf{Z}} & M & E & M & O & R & Y
\end{array}
$$


(Owen et al. 1997; Wolfer et al. 1998) indicating that differences during training do not always reflect differences in spatial search behavior during the probe. Thus, the difference in escape latency between $\alpha 7$ mutant and wild-type mice must be interpreted with caution, and likely does not reflect a difference in learning per se.

Recent reports show that $\alpha$-BTX receptors contribute to cholinergic synaptic transmission in the hippocampus. Presynaptic terminals containing $\alpha 7$ nAChRs can mediate the necessary $\mathrm{Ca}^{2+}$ influx required for glutamate release (Gray et al. 1996). In addition, medial septal cholinergic innervation on somatic CA1 interneurons respond to ACh with a fast, rapidly desensitizing current (Frazier et al. 1998). This current is mediated by nicotinic, not muscarinic receptors. The $\alpha 7$ subunit is likely involved in this current because it can be blocked by $\alpha$-BTX and methyllycaconitine (MLA), which are $\alpha 7$-selective antagonists (Frazier et al. 1998). Acra7-deficient mice lack $\alpha$-BTX binding and fast nicotinic currents in hippocampus (OrrUrtreger et al. 1997). The present behavioral findings indicate that $\alpha 7 \mathrm{nAChR}$-mediated cholinergic synaptic transmission is not necessary for mice to display normal conditioned fear or spatial learning.

The $\alpha 7$ and $\beta 2$ subunits appear to be the predominant subunits in the hippocampus, suggesting that receptors with these subunits are likely to contribute to the effects of nicotine on learning and memory. Picciotto et al. (1995) showed that $\beta 2$ deficient mice display abnormal avoidance learning, but normal spatial learning in the Morris task. 32 -Deficient mice also did not respond to the performance-enhancing effects of nicotine on avoidance performance. These findings show that the $\beta 2$ subunit is important for avoidance learning. Preliminary findings indicate that the Acra7-deficient mice displayed normal passive avoidance learning and memory (data not shown) Thus, it appears that the $\alpha 7$ subunit is not critical for a behavioral response that is affected in $\beta 2$ mutant mice suggesting that different nicotinic receptors contribute to different behavioral responses.

A wide range of prepulse inhibition responses (Bullock et al. 1997; Paylor and Crawley 1997; Logue et al. 1997) and hippocampal auditory gating responses (Stevens et al. 1996) are observed among various inbred strains of mice indicating that both measures of sensory gating are under genetic control. In addition, several findings indicate that levels of sensory gating are associated with a difference in levels of hippocampal $\alpha$-BTX that sug- gests a role for $\alpha 7 \mathrm{nAChR}$ in gating of auditory stimuli. First, levels of gating of hippocampalevoked responses to auditory stimuli are correlated with hippocampal $\alpha$-BTX (Stevens et al. 1996). Second, Bullock et al. (1997) found that low levels of prepulse inhibition were associated with low levels of $\alpha$-BTX binding, which is consistent with the findings by Stevens et al. (1996). Although the correlation $(R=-0.773)$ reported by Bullock et al. (1997) was not statistically significant $(P=0.072)$, it was based on the analysis of only six inbred strains. Additional studies that include more inbred strains will be necessary to further understand the strength of the association between levels of prepulse inhibition and $\alpha$-BTX binding. Finally, $\alpha 7$ mRNA levels are correlated with hippocampalevoked responses (Stevens et al. 1996). Further support for the role of $\alpha 7 \mathrm{nAChR}$ receptors in sensorimotor gating comes from antisense oligonucleotide experiments with rats. Rats treated with $\alpha 7$ antisense oligonucleotide had lower levels of $\alpha$-BTX binding and impaired auditory gating (Leonard et al. 1996). Luntz-Leybman et al. (1992) also showed that rats treated with $\alpha$-BTX had impaired auditory gating. Data from these animal studies together with evidence of genetic linkage between impaired sensory gating in schizophrenia and a site on chromosome 15 near the $\alpha 7$ locus (Freedman et al. 1997) support a hypothesis that $\alpha 7 \mathrm{nAChR}$ contributes to gating, and more specifically, that low levels of $\alpha 7$ are associated with poor sensory gating responses (Leonar et al. 1996).

However, the present findings provide no evidence to support the hypothesis that low (or absent) levels of $\alpha 7 \mathrm{nAChR}$ and diminished levels of $\alpha$-BTX binding are associated with poor sensorimotor gating, as assessed by use of the prepulse inhibition paradigm. Acra7-deficient and wild-type mice displayed similar levels of prepulse inhibition by use of both acoustic and tactile startle stimuli. The $\alpha 7$ nAChR sensory gating hypothesis would have predicted that because Acra 7 mutant mice have no $\alpha$-BTX binding or $\alpha 7$ receptors, they should have had impaired prepulse inhibition responses. The reason for the discrepancy between the previous research supporting this hypothesis and the current data is unknown at this time. It is possible that even though sensorimotor gating, as measured with the prepulse inhibition paradigm, is not different between Acra7-deficient and wildtype mice, a phenotypic difference could be identified by studying gating of hippocampal auditoryevoked responses (e.g., Stevens et al. 1996). Future

$$
\begin{array}{llllllllllllllll} 
& E & A & R & N & I & N & G & \boldsymbol{Q} \\
\mathbf{3 1 3} & M & E & M & O & R & Y
\end{array}
$$


studies will examine gating of hippocampal auditory-evoked responses in Acra 7-deficient mice. It is also possible that what is important is not the number of nAChRs, but how they function. For example, inbred strains of mice that have lower $\alpha$ BTX, $\alpha 7$ mRNA, and poor sensory gating may also have $\mathrm{nAChRs}$ with altered function. Perhaps having nAChRs with altered function has a phenotypic effect distinct from having no $\alpha 7$ nAChRs, which could explain why the $\alpha 7$ mutant mice do not have impaired prepulse inhibition. Future studies could examine the behavioral responses of mice with mutations in the $\alpha 7$ gene that produce a receptor with altered function. Data from mice of this type would address the hypothesis that having altered $\alpha 7$ receptor function produces greater phenotypic effects than the absence of $\alpha 7$ receptors. If this hypothesis is correct, it may also be possible to attenuate the impaired sensory gating impairment in particular inbred strains of ice that have low levels of $\alpha 7 \mathrm{nAChR}$ by creating a congenic $\alpha 7 \mathrm{mu}-$ tant line in which these inbred strains would be entirely missing $\alpha 7$ nAChRs.

The traits of mice with gene-targeted mutations may be influenced not only by deficiencies in the protein expressed by the mutated gene, but also by compensatory changes in other gene products. Because the behaviors we studied are likely to be polygenically controlled, it is possible that compensatory changes in other genes have occurred that resulted in the normal expression of some of the behaviors in the Acra7-deficient mice. However, the analyses of a number of knockout mice over the years clearly show that the same genes do not regulate the expression of all of the behaviors we studied. Therefore, it is unlikely that compensatory changes in the same gene products would normalize all of the behaviors in the Acra7-deficient mice. Additional experiments will be necessary to determine whether compensatory changes in other gene products occur in Acra7-deficient mice, and if so, do these changes influence normal behavioral responses.

Because base-line behavioral performance of Acra7-deficient mice appears to be normal, it is now possible to examine the role of $\alpha 7 \mathrm{nAChR}$ in the multitude of behavioral effects of nicotine without base-line differences that can confound interpretations. To date, some of the behavioral effects of nicotine are believed to be attributed to its actions at $\alpha$-BTX receptors (e.g., Miner and Collins 1989; Stevens and Wear 1997). Drugs are being developed to target specific receptor subunits, however, most available drugs affect multiple receptors. The use of mice with genetic mutations is the best technique for identifying the role of particular receptor subtypes in the behavioral pharmacological response of drugs. Future studies will examine the effects of nicotine in Acra7-deficient mice on each of the behavioral responses described in this study. Other studies will also examine nicotine-induced seizures in Acra7-deficient mice, because data with inbred mice suggest that there is an association between $\alpha 7$ nAChRs and nicotine-induced seizures (Miner and Collins 1989). Finally, $\alpha 7$ mutant mice can be used to study the role of $\alpha 7$ receptors in the development of nicotine tolerance and withdrawal. Acra7-deficient mice may also prove useful for developing drugs that target the $\alpha 7$ receptor.

\section{Acknowledgments}

This work was supported by the Council for Tobacco Research, Inc. (grant 4701 to A.O-U. at Tel-Aviv Sourasky Medical Center) and the National Institute of Mental Health Intramural Research Program (R.P., M.N., and J.N.C).

\section{References}

Acri, J.B., N.E. Grunberg, and D.E. Morse. 1991. Effects of nicotine on the acoustic startle reflex amplitude in rats. Psychopharmacology 104: 244-248.

Acri, J.B., D.E. Morse, E.J. Popke, and N.E. Grunberg. 1994a. Nicotine increases sensory gating measured as inhibition of the acoustic startle reflex in rats. Psychopharmacology 114: 369-374.

1994b. Nicotine modulates effects of stress on acoustic startle reflexes in rats: Dependence on dose, stressor and initial reactivity. Psychopharmacology 116: 255-265.

Adler, L.E., L.H. Hoffer, J. Griffith, M. Waldo, and R. Freedman. 1992. Normalization of deficient auditory sensory gating in the relatives of schizophrenics by nicotine. Biol. Psychiatry 32: 607-616.

Alkondon, M. and E.X. Albuquerque. 1993. Diversity of nicotinic acetylcholine receptors in rat hippocampal neurons. I. Pharmacological and functional evidence for distinct structural subtypes. J. Pharmacol. Exp. Ther. 265: 1455-1473.

Bertrand, D. and J. Changeux. 1995. Nicotinic receptor: An allosteric protein specialized for intercellular communication. Neuroscience 7: 75-90.

Bickford, P.C. and K.D. Wear. 1995. Restoration of sensory gating of auditory evoked response by nicotine in fimbria-fornix lesioned rats. Brain Res. 705: 235-240.

Braff, D.L. and M.A. Geyer. 1990. Sensorimotor gating and schizophrenia. Arch. Gen. Psychiatry 47: 181-188.

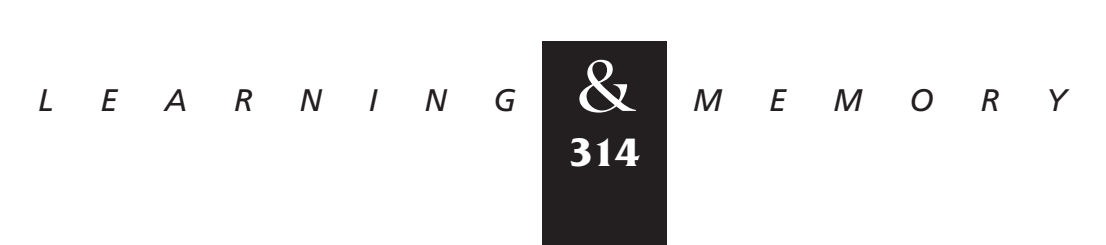


Bullock, A.E., B.S. Slobe, V. Vazquez, and A.C. Collins. 1997. Inbred mouse strains differ in the regulation of startle and prepulse inhibition of the startle response. Behav. Neurosci. 111: 1353-1360.

Cao, W., T. Burkholder, L. Wilkins, and A.C. Collins. 1993. A genetic comparison of behavioral actions of ethanol and nicotine in the mirrored chamber. Phamacol. Biochem. Behav. 45: 803-809.

Cohen, N.J. and H. Eichenbaum. 1993. Memory, amnesia, and the hippocampal system. MIT Press, Cambridge, MA.

Cooper, E., S. Couturier, and M. Ballivet. 1991. Pentameric structure and subunit stoichiometry of a neuronal nicotinic acetylcholine receptor. Nature 350: 235-238.

Court, J. and F. Clementi. 1995. Distribution of nicotinic subtypes in human brain. Alzheimer Dis. Assoc. Disord. 2: 6-14.

Courturier, S., D. Bertrand, J. Matter, M. Hernandez, S. Bertrand, N. Millar, S. Valera, T. Barkas, and M. Ballivet. 1990. A neuronal nicotinic acetylcholine receptor subunit $(\alpha 7)$ is developmentally regulated and forms a homo-oligomeric channel blocked by $\alpha$-BTX. Neuron 5: $847-856$.

Crawley, J.N. and R. Paylor. 1997. A proposed test battery and constellations of specific behavioral paradigms to investigate the behavioral phenotypes of transgenic and knockout mice. Horm. Behav. 31: 197-211.

Curzon, P., D.J. Kim, and M.W. Decker. 1994. Effect of nicotine, lobeline, and mecamylamine on sensory gating in the rat. Phamacol. Biochem. Behav. 49: 877-882.

Curzon, P., J.D. Brioni, and M.W. Decker. 1996. Effect of intraventricular injections of dihydro-beta-erythroidine $(\mathrm{DH} \beta \mathrm{E})$ on spatial memory in the rat. Brain Res. 714: 185-191.

Decker, M.W. and M.J. Majchrzak. 1992. Effects of systemic and intracerebroventricular administration of mecamylamine, a nicotinic cholinergic antagonist, on spatial memory in rats. Psychopharmacology 107: 530-534.

Decker, M.W., M.J. Majchrzak, and D.J. Anderson. 1992. Effects of nicotine on spatial memory deficits in rats with septal lesions. Brain Res. 572: 281-285.

Decker, M.W., M.J. Majchrzak, and S.P. Arneric. 1993. Effects of lobeline, a nicotinic receptor agonist, on learning and memory. Pharmacol. Biochem. Behav. 45: 571-576.

Decker, M.W., J.D. Brioni, J.P. Sullivan, M.J. Buckley, R.J. Radek, J.L. Raszkiewicz, C.H. Kang, D.J.B. Kim, W.J. Giardina, J.T. Wasicak et al. 1994.

(S)-3-methyl-5-(1-methyl-2-pyrrolidinyl)isoxazole (ABT 418): A novel cholinergic ligand with cognitive-enhancing and anxiolytic activities: II. In vivo characterization. J. Pharmacol. Exp. Ther. 270: 319-328.
Dineley-Miller, K. and J. Patrick. 1992. Gene transcripts for the nicotinic acetylcholine receptor subunit, Beta4, are distributed in multiple areas of the rat central nervous system. Mol. Brain Res. 16: 339-344.

Frazier, C.J., Y.D. Rollins, C.R. Breese, S. Leonard, R. Freedman, and T.V. Dunwiddie. 1998. Acetylcholine activates an $\alpha$-bungarotoxin-sensitive nicotinic current in rat hippocampal interneurons, but not pyramidal cells. J. Neurosci. 18: 1187-1195.

Freedman, R., L.E. Adler, M.C. Waldo, E. Pachtman, and R.D. Franks. 1983. Neurophysiological evidence for a defect in inhibitory pathways in schizophrenia: Comparison of medicated and drug-free patients. Biol. Psychiatry 18: $537-551$.

Freedman, R., L.E. Adler, P. Bickford, W. Byerley, H. Coon, C.M. Cullum, J.M. Griffith, J.G. Harris, S. Leonard, C. Miller et al. 1994. Schizophrenia, nicotinic receptors, and cigarette smoking. Harvard Rev. Psychiatry 2: 179-192.

Freedman, R., H. Coon, M. Myles-Worsley, A. Orr-Urtreger, A. Olincy, A. Davis, M. Polymeropoulos, J. Holik, J. Hopkins, M. Hoff et al. 1997. Linkage of a neurophysiological deficit in schizophrenia to a chromosome 15 locus. Proc. Natl. Acad. Sci. 94: 587-592.

Geyer, M.A. and D.L. Braff. 1987. Startle habituation and sensorimotor gating in schizophrenia and related animal models. Schizophr. Bull. 13: 643-668.

Gray, R., A.S. Rajan, K.A. Radcliffe, M. Yakehiro, and J.A. Dani. 1996. Hippocampal synaptic transmission enhanced by low concentrations of nicotine. Nature 383: 713-716.

Keyser, K.T., L.R. Britto, R. Schoepfer, P. Whiting, J. Cooper, W. Conroy, A. Brozozowska-Prechtl, H.J. Karten, and J. Lindstrom. 1993. Three subtypes of

alpha-bungarotoxin-sensitive nicotinic acetylcholine receptors are expressed in chick retina. J. Neurosci. 13: 442-454.

Kumari, V., P.A. Cotter, S.A. Checkley, and J.A. Gray. 1997. Effect of acute subcutaneous nicotine on prepulse inhibition of the acoustic startle reflex in healthy male non-smokers. Psychopharmacology 132: 389-395.

Leonard, S., C. Adams, C.R. Breese, L.E. Adler, P. Bickford, W. Byerley, H. Coon, J.M. Griffith, C. Miller, M.

Myles-Worsley et al. 1996. Nicotinic receptor function in schizophrenia. Schizophr. Bull. 22: 431-445.

Levin, E.D. 1992. Nicotinic systems and cognitive function. Psychopharmacology 108: 417-431.

Lippiello, P.M., M. Bencherif, J.A. Gray, S. Peters, G. Grigoryan, H. Hodges, and A.C. Collins. 1996. RJR-2403: A nicotinic agonist with CNS selectivity II. In vivo characterization. J. Pharmacol. Exp. Ther. 279: 1422-1429.

Logue, S.F., E.H. Owen, D.L. Rasmussen, and J.M. Wehner. 1997. Assessment of locomotor activity, acoustic and tactile startle, and prepulse inhibition of startle in inbred mouse

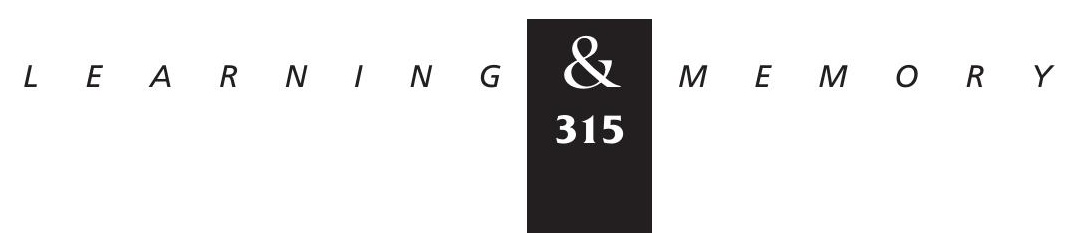




\section{Paylor et al.}

strains and F1 hybrids: Implications of genetic background for single gene and quantitative trait loci analyses. Neuroscience 80: $1075-1086$.

Luntz-Leybman, V., P.C. Bickford, and R. Freedman. 1992. Cholinergic gating of response to auditory stimuli in rat hippocampus. Brain Res. 587: 130-136.

Marks, M.J., L.L. Miner, S. Cole-Harding, J.B. Burch, and A.C. Collins. 1986. A genetic analysis of nicotine effects on open-field activity. Pharmacol. Biochem. Behav.

24: 743-749.

Marks, M., J.A. Stitzel, and A.C. Collins. 1989. Genetic influences on nicotine responses. Phamacol. Biochem. Behav. 33: 667-678.

Meyer, E.M., C.M. de Fiebre, B.E. Hunter, C.E. Simpkins, N. Frauworth, and N.C. deFiebre. 1994. Effects of anabaseine-related analogs on rat brain nicotinic receptor binding and on avoidance behaviors. Drug Dev. Res. 31: 127-134.

Miner, L.L. and A.C. Collins. 1989. Strain comparison of nicotine-induced seizure sensitivity and nicotinic receptors. Pharmacol. Biochem. Behav. 33: 469-475.

Morris, R.G.M. 1981. Spatial localization does not depend upon the presence of local cues. Learn. Motiv. 12: 239-260.

Ohno, M., T. Yamamoto, and S. Watanabe. 1993. Blockade of hippocampal nicotinic receptors impairs working memory but not reference memory in rats. Pharmacol. Biochem. Behav. 45: 89-93.

Orr-Urtreger, A., F.M. Goldner, M. Saeki, I. Lorenzo, L. Goldberg, M. De Biasi, J.A. Dani, J.W. Patrick, and A.L. Beaudet. 1997. Mice deficient in the alpha7 neuronal nicotinic acetylcholine receptor lack alpha-bungarotoxin binding sites and hippocampal fast nicotinic currents. J. Neurosci. 17: 9165-9171.

Owen, E.H., S.F. Logue, D.L. Rasmussen, and J.M. Wehner. 1997. Assessment of learning by the Morris water task and fear conditioning in inbred mouse strains and F1 hybrids: Implications of genetic background for single gene and quantitative trait loci analyses. Neuroscience 80: 1087-1099.

Paylor, R. and J.N. Crawley. 1997. Inbred strain differences in prepulse inhibition of the mouse startle response.

Psychopharmacology 132: 169-180.

Paylor, R., R. Tracy, J. Wehner, and J.W. Rudy. 1994. DBA/2 and $\mathrm{C} 57 \mathrm{BL} / 6$ mice differ in contextual fear but not auditory fear conditioning. Behav. Neurosci. 108: 810-817.

Perry, E.K., J.A. Court, M. Johnson, C.J. Smith, V. James, A.V. Cheng, J.M. Kerwin, C.M. Morris, M.A. Piggott, J.A.

Edwardson, N.J.M. Birdsall, J.T. Turner, and R.H. Perry. 1993. Autoradiographic comparison of cholinergic and other transmitter receptors in the normal human hippocampus. Hippocampus 3: 307-315.
Picciotto, M.R., M. Zoll, C. Lena, A. Bessis, Y. Lallemand, N. LeNovere, P. Vincent, E.M. Pich, P. Brulet, and J.-P. Changeuz. 1995. Abnormal avoidance learning in mice lacking functional high-affinity nicotine receptor in the brain. Nature 374: 65-67.

Schoepfer, R., W.G. Conroy, P. Whiting, M. Gore, and J. Lindstrom. 1990. Brain $\alpha$-bungarotoxin binding protein cDNAs and MAbs reveal subtypes of this branch of the ligand-gated ion channel gene superfamily. Neuron 5: 35-48.

Seguela, P., J. Wadiche, K. Dineley-Miller, J.A. Dani, and J.W. Patrick. 1993. Molecular cloning, functional properties, and distribution of rat brain alpha 7: A nicotinic cation channel highly permeable to calcium. J. Neurosci. 13: 596-604.

Smith, R.D., M.K. Kistler, M. Cohen-Williams, and V.L. Coffin. 1996. Cholinergic improvement of a naturally-occurring memory deficit in the young rat. Brain Res. 707: 13-21.

Stevens, K.E. and K.D. Wear. 1997. Normalizing effects of nicotine and a novel nicotinic agonist on hippocampal auditory gating in two animal models. Pharmacol. Biochem. Behav. 57: 869-874.

Stevens, K.E., J. Meltzer, and G.M. Rose. 1995. Nicotinic cholinergic normalization of amphetamine-induced loss of auditory gating in freely moving rats. Psychopharmacology 119: $163-170$.

Stevens, K.E., R. Freedman, A.C. Collins, M. Hall, S. Leonard, M.J. Marks, and G.M. Rose. 1996. Genetic correlation of inhibitory gating of hippocampal auditory evoked response and $\alpha$-bungarotoxin-binding nicotinic cholinergic receptors in inbred mouse strains. Neuropsychopharmacology 15: 152-162.

Upchurch, M. and J.M. Wehner. 1988. Differences between inbred strains of mice in Morris water maze performance. Behav. Genet. 18: 55-68.

Wolfer, D.P., M. Staglijar-Bozicevic, M.L. Errington, and H.-P. Lipp. 1998. Spatial memory and learning in transgenic mice: Fact or artifact? News Physiol. Sci. (in press).

Zarrindast, M.-R., M. Sadegh, and B. Shafaghi. 1996. Effects of nicotine on memory retrieval in mice. Eur. J. Phamacol. 295: $1-6$.

Received March 4, 1998; accepted in revised form July 17, 1998.

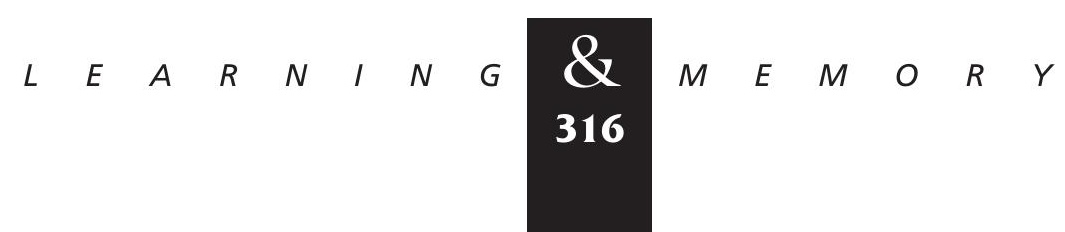




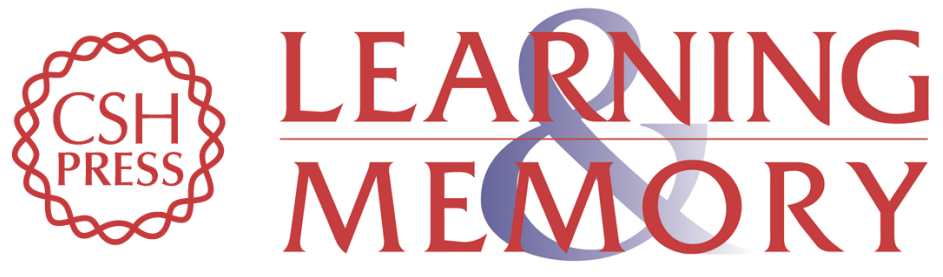

\section{$\alpha 7$ Nicotinic Receptor Subunits Are Not Necessary for Hippocampal-Dependent Learning or Sensorimotor Gating: A Behavioral Characterization of Acra7-Deficient Mice}

Richard Paylor, Michelle Nguyen, Jacqueline N. Crawley, et al.

Learn. Mem. 1998, 5:

Access the most recent version at doi:10.1101//m.5.4.302

References This article cites 51 articles, 8 of which can be accessed free at: http://learnmem.cshlp.org/content/5/4/302.full.html\#ref-list-1

License

Email Alerting

Receive free email alerts when new articles cite this article - sign up in the box at the Service top right corner of the article or click here. 